\title{
Sensitivity of potted ornamental peppers to ethylene ${ }^{(1)}$
}

\author{
MAYANA FERREIRA NASCIMENTO(2), RUSTHON MAGNO CORTEZ DOS SANTOS ${ }^{(2)}$, \\ FERNANDA FERREIRA DE ARAÚJO(3), JOÃO JOSÉ DA SILVA NETO(4), \\ FERNANDO LUIZ FINGER ${ }^{(2)}$, CLAUDIO HORST BRUCKNER ${ }^{(2)}$
}

\begin{abstract}
Many environmental factors affect the post-production shelf life of potted ornamental plants. Exposure to ethylene can reduce the quality of many species, inducing flower, fruit and leaf abscission and senescence. The present study identified ethylene-resistant pepper genotypes during post-production shelf life testing. Potted plants of eleven pepper cultivars were transferred to a 90-L sealed container when they had $30 \%$ of ripe fruits and treated with $10 \mu \mathrm{L} \mathrm{L}^{-1}$ of ethylene for 48 hours. Number of leaves and fruits were counted at the beginning of ethylene exposure and after 48, 96 and 144 hours. The experimental design was completely randomized, with five replicates of individual pots. The cultivars showed varied rates of foliar and fruit abscission. 'Peloteira' showed higher resistance to ethylene, with foliar abscission of 19\%, after 144 hours. For fruit abscission, the cultivars 'Peloteira', 'Jalapeño', 'Stromboli ornamental', 'Malagueta' and 'Rocoto Vermelha' presented a lower percentage of leaf drop, varying between 9 and $34 \%$, after 144 hours of exposure to ethylene. This study showed that ornamental peppers have high genetic diversity regarding ethylene sensitivity.
\end{abstract}

Keywords: Capsicum, growth regulator, leaf and fruit abscission, ornamental plant.

\section{RESUMO}

Sensibilidade ao etileno em pimenta em vaso

Muitos fatores ambientais afetam a fase de pós-produção das plantas ornamentais. A exposição ao etileno é um dos fatores mais importantes que afetam a qualidade de muitas plantas ornamentais em vaso. O trabalho teve como objetivo identificar genótipos de pimenta resistentes ao etileno na fase de pós-produção das pimentas de vaso. Onze cultivares de pimentas foram utilizadas, quando as plantas apresentaram $30 \%$ dos frutos maduros, foram transferidas para um recipiente hermético de $90 \mathrm{~L}$ e tratados com etileno à $10 \mu \mathrm{L} \mathrm{L}^{-1}$ por 48 horas, em seguida, mantidas à temperatura ambiente para posterior análise dos efeitos do etileno. Foram feitas contagens do número de folhas e frutos no tempo zero, 48, 96 e 144 horas após o tratamento com etileno. O delineamento experimental utilizado foi inteiramente casualizado, com cinco repetições. As cultivares apresentaram taxas variadas de abscisão foliar e de frutos. O cultivar 'Peloteira' apresentou maior resistência ao etileno, com abscisão foliar de 19\%, após 144 horas. Para característica abscisão dos frutos, os cultivares 'Peloteira', 'Jalapeño', 'Stromboli ornamental', 'Malagueta' e 'Rocoto vermelha' apresentaram menor porcentagem de abscisão, variando entre 9 e 34\%, após 144 horas de exposição ao etileno.

Palavras-chave: Capsicum, regulador de crescimento, abscisão de folhas e frutos, plantas ornamentais.

\section{INTRODUCTION}

Peppers are an important part of Brazilian plant biodiversity with a large number of varieties that differ in type, color, size, and flavor (PEREIRA and RODRIGUES, 2005; NASCIMENTO et al., 2012). Pepper fruits usually have a spicy taste, although there are also sweet peppers with low heat index (PICKERSGILL, 1997). Peppers can be consumed fresh, boiled or dehydrated, at an immature or mature stage, or in the form of sauces and jams (FINGER and PEREIRA, 2016). Recently, the use of peppers as potted ornamental plants with fruit that can also be consumed has increased, becoming another way to increase the financial return to farmers (FINGER et al., 2012; RÊGO and REGG, 2016).
The search for new ornamental products has increased over the past years (SCHOELLHORN, 2009). In particular, the demand for ornamental peppers has grown both domestically and internationally (FINGER et al., 2015). Sales of decorative peppers in Brazil are still limited to free markets and some supermarkets, but the situation is changing, and more consumers are able to buy peppers in flower shops (RÊGO and REGG, 2016). The many colors of the fruits, which attractively contrast with the foliage (MELO et al., 2014), and the durability, cost benefit and easy handling of the plants add value to ornamental peppers (JUNQUEIRA and PEETZ, 2014).

During post-production phase the plants are exposed to many environmental stresses during shipping and sales, where the plants are subjected to low light, high

\footnotetext{
DOI: http://dx.doi.org/10.14295/oh.v24i4.1458

${ }^{(1)}$ Received in 29/08/2018 and accepted in 20/09/2018

(2) Universidade Federal de Viçosa, Departamento de Fitotecnia, Viçosa-MG, Brazil. *Corresponding author: mayana.f.nascimento@gmail.com

${ }^{(3)}$ Universidade Federal de Viçosa, Departamento de Biologia vegetal, Viçosa-MG, Brazil.

(4) Instituto Federal de Mato Grosso do Sul, Ponta Porã-MS, Brazil.

Licensed by CC BY 4.0
} 
temperatures and mechanical injuries (HOYER, 1996). Such stressful conditions increase ethylene synthesis and action (MAYAK et al., 2004; SIDDIKEE et al., 2011). When plants are exposed to ethylene, sensitive flowers and leaves will abscise or senesce (WOLTERING, 1996). The negative effects of ethylene on sensitive varieties are one of the main factors limiting the commercialization of ornamental peppers (SEGATTO et al., 2013).

Therefore, the objectives of this work were to evaluate the sensitivity of eleven potted pepper cultivars to the effect of ethylene under simulated shipping or marketing.

\section{MATERIAL AND METHODS}

\section{Conducting the experiment}

Ten commercial cultivars of Capsicum: 'Pérola negra' and 'Jalapeño'(Capsicum annuum); 'Malagueta', 'Tabasco', 'Strombolli ornamental', and 'Pirâmide ornamental' (Capsicum frutescens); 'Rocoto vermelha' (Capsicum pubescens); 'Dedo de moça' (Capsicum baccatum), 'Bode vermelha' and 'Biquinho vermelha' (Capsicum chinense), and one Solanum: 'Peloteira' (Solanum pseudocapsicum) were grown in a greenhouse.

Seeds were sown in 200 cell polystyrene trays containing commercial substrate. When the seedlings had four pairs of leaves, one single plantlet was transplanted into a $700 \mathrm{ml}$ pot number $13(10 \mathrm{~cm}$ in height, $9 \mathrm{~cm}$ in basal diameter and $12 \mathrm{~cm}$ in diameter).

\section{Ethylene treatment}

When plants reached the stage of $30 \%$ of full ripe mature fruits, plants were evaluated for sensitivity to ethylene according to Segatto et al. (2013). Pots were placed in 90-liter sealed chambers in the dark simulating stress conditions during transport or storage, and then exposed to $10 \mu \mathrm{L} \mathrm{L}^{-1}$ of ethylene for 48 hours.
Plant quality and longevity were determined after the ethylene treatment, when the pots were transferred to a room simulating the interior conditions of stores, supermarkets and homes of the final consumers at $25 \pm$ $1{ }^{\circ} \mathrm{C}, 8-10 \mu \mathrm{mol} \mathrm{s}{ }^{-1} \mathrm{~m}^{-2}$ of white fluorescent light, and RH $60-65 \%$ and watered when necessary. Percentages of leaf (LA) and fruit abscission (FA) were recorded every two days.

\section{Statistical analysis}

The experimental design was completely randomized, with five replicates. The quantitative data were submitted to analysis of variance, with averages grouping by the Skott-Knott criterion at $1 \%$ probability. Statistical analyzes were performed through the Genes computational program (CRUZ, 2013).

\section{RESULTS AND DISCUSSION}

Significant differences $(p<0.01)$ occurred among the pepper cultivars for leaf and fruit abscission (data not shown), which means that there is genetic variability among the tested cultivars studied that can be exploited in pepper breeding programs.

After 48 hours untreated control plants showed variable rates of foliar abscission among the cultivars. The genotypes were grouped into three distinct classes according to the Skott-Knott criteria. 'Peloteira' (Solanum pseudocapsicum) and 'Malagueta' (C. frutescens) had the lowest leaf abscission, 6 and 17\%, respectively, after 48 exposure to ethylene (Table 1). The cultivars 'Pérola negra' ( $C$. annuum), 'Jalapeño' $(C$. annuum) and 'Biquinho vermelha' $(C$. chinense) showed the highest percentage of foliar abscission, 69, 65 and $98 \%$, respectively, after 48 hours exposure to ethylene (Table 1) (Figure 1).

Table 1. Percent leaf abscission (LA) and fruit abscission (FA) for eleven pepper cultivars after 48, 96 and 144 hours exposure to ethylene.

\begin{tabular}{|l|c|c|c|c|c|c|}
\hline \multicolumn{1}{|c|}{ Cultivars } & \multicolumn{2}{|c|}{$\mathbf{4 8}$ hours } & \multicolumn{3}{c|}{$\mathbf{9 6}$ hours } & F4 hours \\
\hline & LA & FA & LA & FA & LA \\
\hline Pirâmide ornamental & $42 \mathrm{~b}$ & $55 \mathrm{a}$ & $49 \mathrm{~b}$ & $60 \mathrm{a}$ & $67 \mathrm{~b}$ & $62 \mathrm{a}$ \\
\hline Pérola negra & $69 \mathrm{a}$ & $33 \mathrm{a}$ & $84 \mathrm{a}$ & $36 \mathrm{~b}$ & $93 \mathrm{a}$ & $49 \mathrm{a}$ \\
\hline Dedo de moça & $53 \mathrm{~b}$ & $31 \mathrm{a}$ & $77 \mathrm{a}$ & $43 \mathrm{a}$ & $94 \mathrm{a}$ & $49 \mathrm{a}$ \\
\hline Bode vermelha & $39 \mathrm{~b}$ & $38 \mathrm{a}$ & $54 \mathrm{~b}$ & $56 \mathrm{a}$ & $61 \mathrm{~b}$ & $58 \mathrm{a}$ \\
\hline Peloteira & $6 \mathrm{c}$ & $6 \mathrm{~b}$ & $11 \mathrm{c}$ & $8 \mathrm{~b}$ & $19 \mathrm{c}$ & $9 \mathrm{~b}$ \\
\hline Jalapeño & $65 \mathrm{a}$ & $2 \mathrm{~b}$ & $79 \mathrm{a}$ & $24 \mathrm{~b}$ & $91 \mathrm{a}$ & $31 \mathrm{~b}$ \\
\hline Biquinho vermelha & $98 \mathrm{a}$ & $46 \mathrm{a}$ & $100 \mathrm{a}$ & $62 \mathrm{a}$ & $100 \mathrm{a}$ & $63 \mathrm{a}$ \\
\hline Tabasco & $31 \mathrm{~b}$ & $67 \mathrm{a}$ & $71 \mathrm{a}$ & $73 \mathrm{a}$ & $74 \mathrm{~b}$ & $74 \mathrm{a}$ \\
\hline Stromboli ornamental & $49 \mathrm{~b}$ & $11 \mathrm{~b}$ & $78 \mathrm{a}$ & $20 \mathrm{~b}$ & $91 \mathrm{a}$ & $26 \mathrm{~b}$ \\
\hline Malagueta & $17 \mathrm{c}$ & $18 \mathrm{~b}$ & $72 \mathrm{a}$ & $33 \mathrm{~b}$ & $84 \mathrm{a}$ & $35 \mathrm{~b}$ \\
\hline Rocoto vermelha & $39 \mathrm{~b}$ & $15 \mathrm{~b}$ & $88 \mathrm{a}$ & $15 \mathrm{~b}$ & $93 \mathrm{a}$ & $36 \mathrm{~b}$ \\
\hline
\end{tabular}




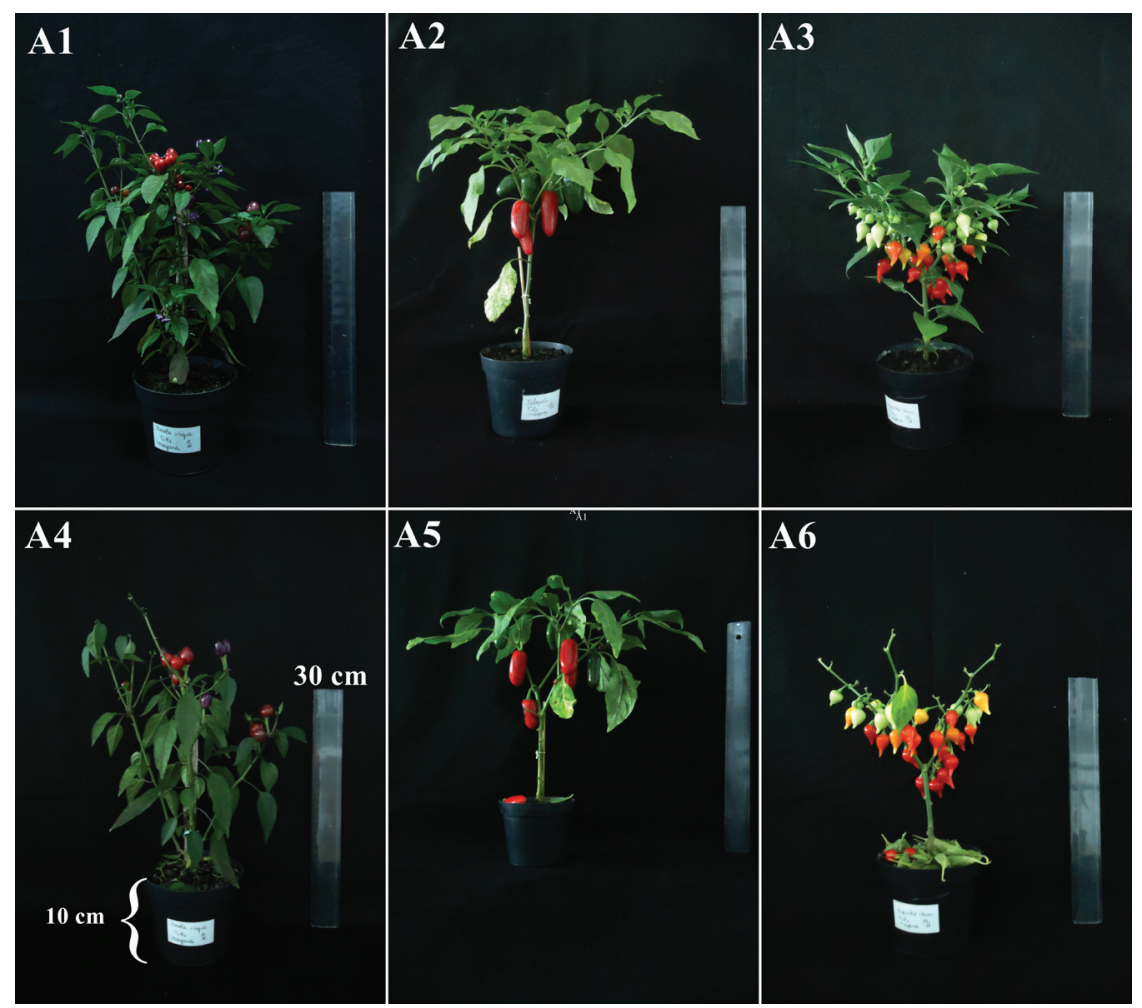

Figure 1. Effect of ethylene on: A1 - 'Pérola Negra' (C. annuum), A2 - 'Jalapeño' (C. annuum) and A3 - 'Biquinho Vermelha' (C. chinense) cultivars. A - before treatment with ethylene; B - 48 hours after exposure to ethylene.

Remaining cultivars had intermediate rates of foliar abscission. Similarly, Lima et al. (2017), evaluating two cultivars of $C$. annuum, reported that cultivar ' $\mathrm{MG}$ 302' showed intermediate sensitivity to ethylene, while 'Calypso' showed complete leaf abscission when exposed to ethylene. Segatto et al. (2013), evaluating four C. annuum ornamental peppers genotypes, reported that ethylene also elicited a severe leaf abscission in plants of the 'Calypso' cultivar after being exposed to $10 \mu \mathrm{L} \mathrm{L}^{-1}$ of ethylene for 48 hours. This demonstrates genetic variability within the same species as has been discussed by Serek et al. (2006).

According to Rêgo et al. (2015), in developing new cultivars, it is important to select genotypes that have specific characteristics, such as rapid growth, adequate architecture for commercialization, resistance to aging and extended post-production shelf life. Hybridization between contrasting genotypes produces extremely heterogeneous progeny, which may result in the production of cultivars with higher tolerance to ethylene (OLSEN et al., 2015).

Leaf abscission increased at 96 and 144 hours after the exposure to ethylene. The cultivars were grouped in three distinct classes; 'Peloteira' had the lowest sensitivity to ethylene, with foliar abscission of 11 and $19 \%$, respectively, over time (Table 1) (Figure 2).

On the other hand, the exposure of 'Biquinho Vermelha' to $10 \mu \mathrm{L} \mathrm{L}^{-1}$ of ethylene induced the abscission of $100 \%$ of leaves at 96 and 144 hours (Figure 3). The remaining cultivars had intermediate foliar abscission. Nascimento et al. (2015) evaluated two genotypes of peppers and two simple hybrids, showing different ethylene sensitivity levels, where the '76 x BP' and 'DR x BP' hybrids presented lower sensitivity to ethylene, less than $50 \%$ foliar abscission, 144 hours after exposure to ethylene. 


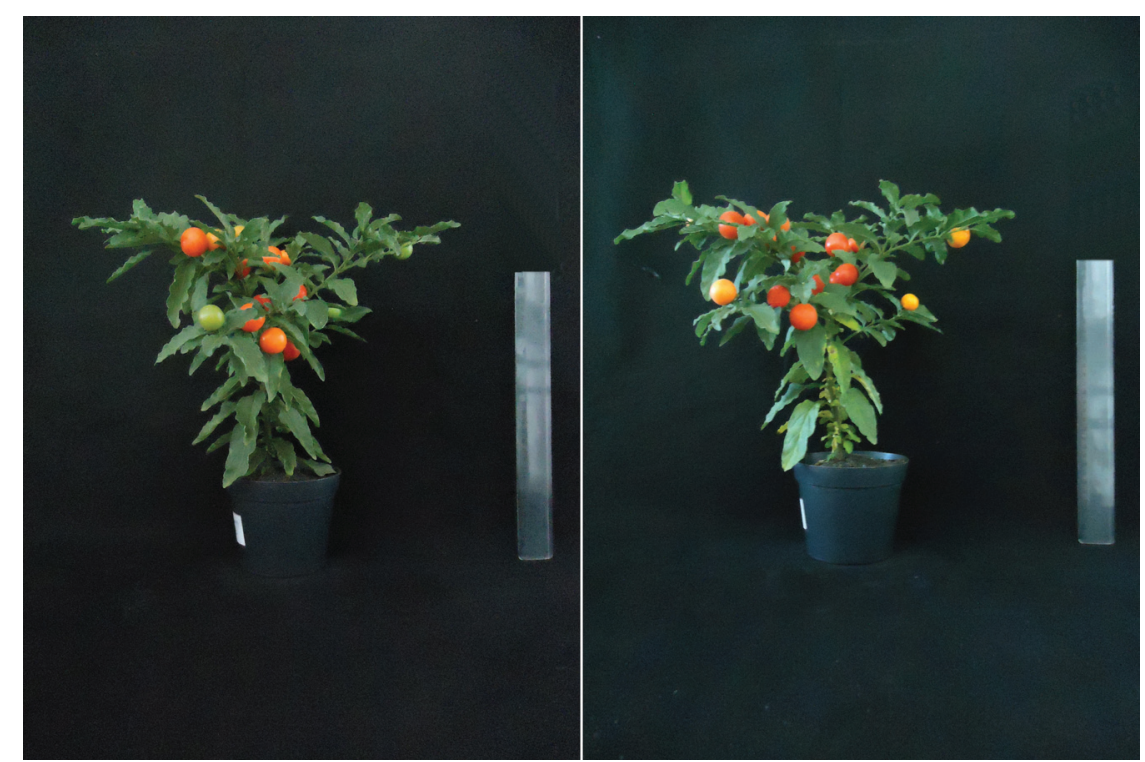

Figure 2. Effect of ethylene on 'Peloteira' cultivar (S. pseudocapsicum). A - before treatment with ethylene; B - 144 hours after exposure to ethylene.

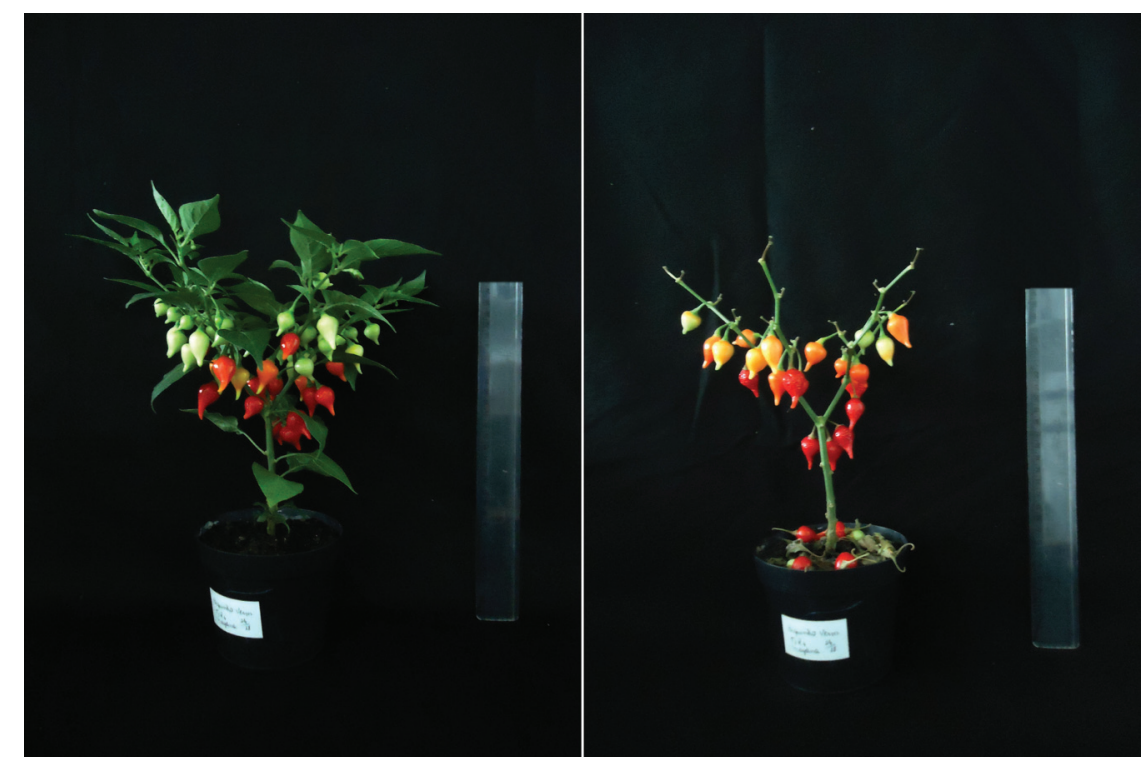

Figure 3. Appearance of the 'Biquinho Vermelha' pepper cultivar (C. chinense). A - before treatment with ethylene, B - after treatment with ethylene for 144 hours.

The sensitivity of ornamental plants to ethylene is generally established at family level, but there can be marked differences between species and cultivars (SEREK et al., 2006; CORDEIRO et al., 2011). Santos et al. (2013) found variation for resistance to ethylene in a segregating population $\left(\mathrm{F}_{2}\right)$ of ornamental pepper $C$. annuum ranging from genotypes that were totally sensitive to ethylene to others that were resistant. Commercially, cut stems of peppers with a high degree of sensitivity to ethylene for foliar abscission, but resistant to fruit abscission, would be important in the making of bouquets, as an alternative form of commercialization of ornamental peppers. On cut stems, growers often have to manually remove the foliage to improve the presentation of the fruit and ethylene could be used to make this laborious process easier.

Regarding fruit abscission, the cultivars were divided into two distinct groups at 48, 96 and $144 \mathrm{~h}$. The cultivars 'Peloteira', 'Jalapeño', 'Stromboli ornamental', 'Malagueta' and 'Rocoto' exhibited lower fruit abscission (Table 1). The other cultivars presented more than $30 \%$ of abscission of the fruits, making it unviable to commercialize as ornamental plants. The efficacy of ethylene on the abscission of the pepper fruit depends on the exposure period, concentration, temperature, and 
stage of development and sensitivity of species or varieties (Finger et al., 2015). Brown (1997) adds that the different intensities of fruit abscission in response to ethylene may be related to the increase of ethylene.

Physiological responses to the presence of ethylene in fruits and ornamental plants require that the organs have receptors to allow binding of ethylene molecules (SEREK et al., 2006). In cultivars of ornamental peppers sensitive to ethylene, the application of ethylene action inhibitors, silver ion or 1-methylcyclopropene, prolong shelf-life (FINGER et al., 2017; LIMA et al., 2017) by binding to the receptors, making them a useful option to maintain the plant quality during transport and marketing to the final consumer. Therefore, the use of inhibitors of ethylene synthesis or action should be tested to increase the postharvest life of the peppers.

\section{CONCLUSIONS}

Ethylene sensitivity is an important factor that affects the commercialization of peppers, since the harmful effects caused by ethylene decrease the quality and the shelf life of ornamental plants (FINGER et al., 2012). The incorporation of resistance genes into new cultivars will improve the longevity of ornamental plants (FINGER et al., 2015). This study showed that ornamental peppers have high genetic diversity regarding ethylene sensitivity. Breeding programs aimed at reducing the response to ethylene can be developed by crossing among resistant genotypes.

\section{ACKNOWLEDGMENTS}

The authors are grateful for the financial support by CNPq (National Council for Scientific and Technological Development) and CAPES (Coordination for the Improvement of Higher Education Personnel).

\section{AUTHORS CONTRIBUTIONS}

M.F.N. (D)0000-0002-9844-0594, R.M.C.S. (D)0000-0002-6967-2871, F.F.A. (D) $0000-0001-7420-9614$ and J.J.S.N. D0000-0002-8094-9982: designed and performed the experiment, analyzed the data and drafted the article; F.L.F. (D)0000-0002-4046-9634 and C.H.B. (D)0000-0002-6249-3686 reviewed and supplemented the writing, designed the project, analyzed the data and wrote the article with contributions from all authors.

\section{REFERENCES}

BROWN, K.M. Ethylene and abscission. Physiologia Plantarum, v.100, p.567-576,1997. DOI: https://doi. org/10.1111/j.1399-3054.1997.tb03062.x.

CORDEIRO, D.C.; FINGER, F.L.; SANTOS, J.S.; KARSTEN, J.; BARBOSA, J.G. Sensibilidade da rosa 'Osiana' ao etileno. Bragantia, v.70, n.3, p.677681, 2011. DOI: http://dx.doi.org/10.1590/S0006-
87052011000300025.

CRUZ, C.D. Genes: a software package for analysis in experimental statistics and quantitative genetics. Acta Scientiarum, v.35, n.3, p.271-276, 2013. DOI: http:// dx.doi.org/10.4025/actasciagron.v35i3.21251.

FINGER, F.L.; RÊGO, E.R.; SEGATTO, F.B.; NASCIMENTO, N.F.F.; RÊGO, M.M. Produção e potencial de mercado para pimenta ornamental. Informe Agropecuário, v.33, p.14-20, 2012.

FINGER, F.L.; SILVA, T.P.; SEGATTO, F.B.; BARBOSA, J.G. Inhibition of ethylene response by 1-methylcyclopropene in potted ornamental pepper. Ciência Rural, v.45, n.6, p.964-969, 2015. DOI: http:// dx.doi.org/10.1590/0103-8478cr20131386.

FINGER, F.L.; PEREIRA, G.M. Physiology and postharvest of pepper fruits. In: RÊGO, E.R.; RÊGO, M.M.; FINGER, F.L. Production and Breeding of Chilli Peppers (Capsicum spp). Cham: Springer, 2016. p.27-40.

HOYER, L. Critical ethylene exposure for Capsicum annuum "Janne is dependent on an interaction between concentration, duration and developmental stage. Journal of Horticultural Science, v.71, p.621-628, 1996. DOI: https://doi.org/10.1080/14620316.1996.11515442.

JUNQUEIRA, A.H.; PEETZ, M.S. O setor produtivo de flores e plantas ornamentais do Brasil, no período de 2008 a 2013: atualizações, balanços e perspectivas. Revista Brasileira de Horticultura Ornamental, v.20, n.2, p.115$120,2014$.

LIMA, P.C.C.; RIBEIRO, W.S.; OLIVEIRA, M.M.T.; COSTA, L.C.; FINGER, F.L. Ethylene, 1-methylcyclopropene and silver thiosulfate on the postproduction of ornamental pepper. Ciência Rural, v.47, n.2, p.1-8, 2017. DOI: http://dx.doi.org/10.1590/0103$8478 \mathrm{cr} 20151611$.

MAYAK, S.; TIROSH, T.; GLICK, B.R. Plant growthpromoting bacteria confer resistance in tomato plants to salt stress. Plant Physiology Biochemistry, v.42, p.565572, 2004. DOI: 10.1016/j.plaphy.2004.05.009.

MELO, L.F.; GOMES, R.L.F.; SILVA, V.B.; MONTEIRO, E.R.; LOPES, A.C.A.; PERON A.P. Potencial ornamental de acessos de pimenta. Ciência Rural, v.44, n.11, p.2010-2015, 2014. DOI: http://dx.doi.org/10.1590/0103$8478 \mathrm{cr} 20131306$.

NASCIMENTO, N.F.F.; RÊGO, E.R.; RÊGO, M.M.; NASCIMENTO, M.F.; ALVES, L.I. Compatibilidade em cruzamentos intra e interespecíficos em pimenteiras ornamentais. Revista Brasileira de Horticultura Ornamental, v.18, n.1, p.58-61, 2012. 
NASCIMENTO, N.F.F.; RÊGO, E.R.; NASCIMENTO, M.F.; SANTOS, R.M.C.; FINGER, F.L.; BRUCKNER, C.H.; RÊGO, M.M. Comparison among hybrids and preselected cultivars for resistance to ethylene in ornamental peppers. Acta Horticulturae, v.1060, p.327-332, 2015.

OLSEN, A.; LUTKEN, H.; HEGELUND, J.N.; MULLER, R. E. Ethylene resistance in flowering ornamental plants - improvements and future perspectives. Horticulture Research, v.2, p. 1-9, 2015. DOI: 10.1038/hortres.2015.38.

PEREIRA, T.N.S.; RODRIGUES, R. Recursos genéticos em Capsicum: situação atual e perspectivas. In: LIMA, M.C. Recursos genéticos de hortaliças: riquezas naturais. São Luís: Instituto Interamericano de Cooperação para a Agricultura, 2005. p.137-159.

PICKERSGILL, B. Genetic resources and breeding of Capsicum spp. Euphytica, v.96, p.129-133, 1997.

RÊGO, E.R.; RÊGO, M.M.; FINGER, F.L. Methodological basis and advances for Ornamental Pepper Breeding Program in Brazil. Acta Horticulturae, v.1087, p.309314, 2015.

RÊGO, E.R.; RÊGO, M.M. Genetics and breeding of Chilli Pepper Capsicum spp. In: RÊGO, E.R.; RÊGO, M.M.; FINGER, F.L. Production and Breeding of Chilli Peppers (Capsicum spp). Cham: Springer, 2016. 27-40.

SANTOS, R.M.C.; RÊGO, E.R.; NASCIMENTO, M.F.; NASCIMENTO, N.F.F.; BORÉM, A.; FINGER, F.L.; COSTA, D.S.; RÊGO, M.M. Ethylene resistance in a $\mathrm{F}_{2}$ population of Ornamental Chili Pepper (Capsicum annuum). Acta Horticulturae, v.1000, p.433-438, 2013.
SANTOS, R.M.C.; RÊGO, E.R.; FERREIRA, A.P.S.; NASCIMENTO, M.F.; NASCIMENTO, N.F.F.; COCA, G.C.; RÊGO, M.M.; BORÉM, A.; FINGER, F.L. Inhibition of ethylene action by 1-MCP in post-production Ornamental Peppers. Acta Horticulturae, v.1060, p.55-260, 2015.

SCHOELLHORN, R. Strategies for plant introduction and market trends in the US. Acta Horticulturae, v.813, p.101-106, 2009.

SEGATTO, F.B.; FINGER, F.L.; BARBOSA, J.G.; RÊGO, E.R.; PINTO, C.M.F. Effects of ethylene on the post-production of potted ornamental peppers (Capsicum annuum L.). Acta Horticulturae, v.1000, p.217-222, 2013.

SEREK, M.; WOLTERING, E.J.; SISLER, E.C.; FRELLO, S.; SRISKANDARAJAH, S. Controlling ethylene responses in flowers at the receptor level. Biotechnology Advances, v.24, p.368-381, 2006. DOI: https://doi. org/10.1016/j.biotechadv.2006.01.007.

SIDDIKEE, M.A.; CHAUHAN, O.S.; TONGMIN, S.A. Regulation of ethylene biosynthesis under salt stress in Red Pepper (Capsicum annuum L.) by 1-aminocyclopropane-1carboxylic acid (ACC) deaminase producing halotolerant bacteria. Plant Growth Regulation, v.10, p.1-8, 2011.

WOLTERING, E. Effects of ethylene on ornamental pot plants: a classification. Scientia Horticulturae, v.31, p.83-94, 1996. DOI: https://doi.org/10.1016/03044238(87)90054-9. 